\title{
Reversal of Fortune in a Small, Open Economy: Regional GDP in Belgium, 1896-2000
}

\author{
Erik Buyst
}

Vives discussion paper 8

September 2009

VIVES

Naamsestraat 61 bus 3510

3000 Leuven - Belgium

Tel: +32 16324222

www.econ.kuleuven.be/vives 


\title{
Reversal of Fortune in a Small, Open Economy: Regional GDP in Belgium, 1896-2000
}

\author{
Erik Buyst ${ }^{1}$ \\ Centre for Economic Studies and Vives, University of Leuven
}

\begin{abstract}
In this paper we present estimates of regional GDP per capita for certain benchmark years during the first half of the $20^{\text {th }}$ century using the method proposed by Geary and Stark (2002). After testing the robustness of the Geary and Stark methodology for the Belgian situation, these estimates are linked to the official regional GDP figures, available since 1955, so that we can cover the whole $20^{\text {th }}$ century. Next we test the contrast put forward by many historians between a 'poor Flanders' and a relatively 'prosperous Wallonia' around 1900. For the remainder of the analysis Belgium's nine provinces are used as a geographical unit to take a broader view than just the Flanders/Wallonia controversy. It shows a dramatic reversal of fortune between the northern and southern provinces. Finally, it is investigated whether the $20^{\text {th }}$ century witnessed a process of convergence.
\end{abstract}

\section{Samenvatting}

In deze studie gebruiken we de methode ontwikkeld door Geary en Stark om ramingen te maken van het bruto regionaal product per hoofd van de bevolking voor bepaalde steekjaren tijdens de eerste helft van de $20^{\text {ste }}$ eeuw. In eerste instantie wordt getest of deze methode bruikbaar is voor de

\footnotetext{
${ }^{1}$ The paper benefitted from comments during the ESF Globaleuronet Conference at the European University Institute in Florence. We thank Rien van de Wall and HISGIS for their help with the historical maps.
} 
Belgische situatie. Nadien worden de ramingen gekoppeld aan de officiële regionale rekeningen, beschikbaar sinds 1955, zodat een overzicht voor de gehele $20^{\text {ste }}$ eeuw beschikbaar komt. Verder testen we de tegenstelling die in de historische literatuur wordt geponeerd tussen een 'arm Vlaanderen' en een relatief 'welvarend Wallonië' rond 1900. Voor de rest van de analyse gebruiken we het provinciale niveau als geografische omschrijving om een nauwkeurig beeld te krijgen van de economische verschuivingen. Een en ander bevestigt de dramatische ommekeer in relatieve welvaart tussen de noordelijke en zuidelijke provincies. Ten slotte onderzoeken we of er sprake is van economische convergentie in de loop van de $20^{\text {ste }}$ eeuw.

\section{Introduction}

Belgium is known for its longstanding linguistic quarrels between the northern Dutch-speaking part - Flanders - and the southern French-speaking part Wallonia $^{2}$. The political, sociological and cultural aspects of the conflict have received much scholarly attention, but this is far less so for the economic roots of the divide (Deprez and Vos, 1998; Witte and Van Velthoven, 1999; Smith and Wistrich, 2007). Nevertheless Flanders and Wallonia followed quite distinct patterns of economic development during the $19^{\text {th }}$ and $20^{\text {th }}$ centuries. For a long time Flanders was the poorer part of Belgium, but this changed dramatically in the course of the 1960s. Flanders did not only surpass Wallonia in per capita GDP but built up a considerable lead in the 1970s and 1980s. This spectacular reversal of fortune complicated further the already difficult relations between the two linguistic groups as Wallonia could no longer compensate its demographic minority position by economic dominance (Goossens, 2003; Conway 2005).

Despite the relevance of the subject few economists or economic historians have analyzed long run regional developments in Belgium. An important exception is the investigation of historical shifts in regional employment.

\footnotetext{
${ }^{2}$ We ignore the continuous conflicts surrounding the bilingual status of Brussels.
} 
Olyslager (1947) pioneered this type of research for the manufacturing sector, but it was De Brabander (1981) who first presented a detailed account of the regional employment dynamics between 1846 and 1970 for all sectors in the Belgian economy.

In this paper we add a new perspective to the debate by presenting estimates of regional GDP per capita for certain benchmark years using the method proposed by Geary and Stark (2002). These estimates are linked to the official regional GDP figures, available since 1955, so that we can cover the whole $20^{\text {th }}$ century. Belgium's nine provinces are used as a geographical unit to take a broader view than just the Flanders/Wallonia controversy. Furthermore we test the contrast put forward by many historians between a 'poor Flanders' and a relatively 'prosperous Wallonia' around 1900 (e.g. Witte, 1983; Hannes, 2007). Of course such generalizations have to be put into their proper context. Nobody disputes that both Flanders and Wallonia were characterized by large income inequalities in that period. Finally, it is investigated whether the $20^{\text {th }}$ century witnessed a process of convergence.

\section{Method}

The official regional GDP figures, available since 1955, are calculated by using a top-down approach: per subsector Belgian gross value added at factor costs is distributed over the nine provinces. For the 1955-1975 period the former National Institute for Statistics (NIS) developed several distribution procedures depending on the availability of data. For some subsectors regional input and output figures could be obtained, but often the regional wage sum, employment, or fiscal statistics, etc. had to be used (NIS, 1966). After 1975 consistent official regional GDP figures were published by the newly established National Accounts Institute. The distribution procedures became ever more sophisticated and detailed, but the basic principles remained largely the same (INR, 1999). Other innovations were the introduction of the ESER 1979 and ESR 1995 methods, respectively in 1975 
and 1995. For our purpose - relative per capita GDP per province - the impact of these changes remained limited.

It is impossible to replicate the NIS-method for the pre-1955 period. Several regional data were only collected from the late 1950s and early 1960s onwards precisely with the purpose of starting up regional GDP statistics (NIS, 1966). Geary and Stark (2002) propose a method to circumvent this problem. They use historical information on wages and employment, grouped by sector and by 'country', to allocate UK GDP across England, Ireland, Scotland and Wales for certain benchmark years during the 1861-1911 period. The obvious question then becomes: does the Geary and Stark approach work for relatively small geographical entities as the nine Belgian provinces? Therefore we test the method by comparing the estimates generated by the Geary and Stark procedure with the official regional GDP figures.

We need an overlapping year in which similar sources and data are available that can be used later on for the pre-1955 historical reconstruction. To start with the Geary and Stark method requires an employment matrix by sector agriculture, industry, services - and per province. De Brabander (1981) derived consistent long run provincial employment series per branch from census data. The first population, industrial and commercial census held after 1955 was organized in 1961, so we take that year as a benchmark. Next we need wages by sector and per province. Often such information was collected in the framework of industrial and commercial censuses, but this was no longer the case after 1947. Since that period the annual reports of the Social Security Agency contain similar material for industry and services. They provide e.g. separate regional wage data for female/male labour and bluecollar/white-collar workers (RMZ, 1961). Regional wages of agricultural workers are based on a sample of 66 large farms relatively evenly distributed over the country (LEI, 1961). This seems a rather crude approach but by 1961 the share of agriculture in total employment was almost insignificant. Finally, Belgian value added per sector at factor costs is taken from NIS (1966). 
Table 1 compares the official and estimated regional GDP figures per capita in 1961. Most relative deviations remain very much in line with those of a similar test reported by Geary and Stark (2002) for England, Northern Ireland, Scotland and Wales in 1971. For Luxemburg and Namur the deviations are somewhat larger probably because these provinces offered relatively few employment opportunities (see Annex 1) so that the law of large numbers could not play sufficiently. Nevertheless the estimated regional GDP figures per capita are able to reproduce the main picture: relatively rich provinces remain the prosperous ones and the same holds for the poor provinces. We conclude that the Geary and Stark method is a useful tool to estimate regional GDP figures in Belgium for the first half of the $20^{\text {th }}$ century.

Table 1: Relative regional GDP per capita in 1961 (current prices, Belgium = 100)

\begin{tabular}{|l|c|c|c|}
\hline & Official & Estimated & Difference (in \%) \\
\hline Antwerp & 106,9 & 103,8 & $-2,9$ \\
\hline Brabant & 126,7 & 131,8 & 4,1 \\
\hline West Flanders & 89,2 & 84,9 & $-4,8$ \\
\hline East Flanders & 81,1 & 84,3 & 4,0 \\
\hline Hainaut & 90,6 & 88,6 & $-2,2$ \\
\hline Liège & 111,0 & 111,3 & 0,3 \\
\hline Limburg & 68,7 & 70,8 & 3,0 \\
\hline Luxemburg & 76,3 & 70,1 & $-8,1$ \\
\hline Namur & 90,2 & 81,9 & $-9,2$ \\
\hline
\end{tabular}

Source: Official data: NIS (1966)

Estimated: see text.

\section{Historical reconstruction}


We note that the borders of the nine Belgian provinces remained fairly stable throughout the $20^{\text {th }}$ century (see maps). A first exception was the Versailles Treaty of 1919 which led to the annexation of the Eupen-Malmedy area from Germany: it increased the population of the Liège province with 6.8 percent. $A$ second redrawing happened in 1962 when 6.6 percent of the population of West Flanders was transferred to Hainaut (Annuaire statistique, 1923-1924; $1962 ; 1963)^{3}$. The effects of these border changes on regional GDP per capita remained limited.

As indicated earlier, De Brabander (1981) derived consistent long run regional employment series per sector from census data. For a small country characterized by mass commuting since the beginning of the $20^{\text {th }}$ century it is important to point out that De Brabander's figures refer to the province where people were working, not where they were living. The reconstruction of regional wage figures is virgin territory in Belgian historiography (Scholliers, 1991). Therefore we analyze the industrial and commercial censuses organized during the period under consideration. Unfortunately only the censuses of 1896, 1937 and 1947 collected detailed wage data (MIT, 1901; CDS, 1940; NIS, 1951-1952). ${ }^{4}$ What the service sector is concerned, the 1896 census only reported wages of blue-collar workers in (private) transportation firms. A test for 1937 indicates however that these wages are a reasonably good predictor of the regional distribution of the remainder of the private service sector.

In the case of agricultural wages we have to rely on various sources. The Ministry of Agriculture published regional wage data for 1947, but how this material was collected remains unclear (Ministerie van Landbouw, 1948). Nevertheless the data seem reliable as the production and distribution of agricultural products was under tight government control in the aftermath of

\footnotetext{
${ }^{3}$ In 1995 the province of Brabant was split up: for the year 2000 we added up the three new entities.

${ }^{4}$ A difference with the UK wage data is that we dispose of both male and female wages, and that we have separate wages for private services such as transport, wholesale and retail trade, banking and insurance, hotels, restaurants and entertainment. What services is concerned Geary and Stark (2002) had to rely on a weighted average of the agriculture and industry wage series.
} 
World War II (Blomme, 1993). For 1937 we are on firmer ground. In the wake of the industrial and commercial census of the same year the government decided to organize a large-scale wage inquiry in the agricultural sector as well (CDS, 1939). What the end of the $19^{\text {th }}$ century is concerned we rely on the agricultural census of 1895 (MATP, 1900). The wages reported there refer to an inquiry held among mayors of rural municipalities and not among agricultural workers as was the case in the 1937 inquiry. These mayors were more often than not large landowners, which induced a certain bias in the data. Since we are interested in relative wages this bias probably does not concern us too much. Finally, Belgian value added per sector at factor costs is taken from Blomme (1993) and Soete (1999).

\section{Results}

Map 1 shows the geographical distribution of relative GDP per capita in 1896. It confirms the clear-cut divide between a 'poor Flanders' and a 'prosperous Wallonia' put forward in the literature. All four Dutch-speaking provinces West Flanders, East Flanders, Antwerp and Limburg - showed a GDP per caput below the Belgian average. Three out of four French-speaking provinces - Hainaut, Namur and Liège - boasted an above average per capita GDP. Luxemburg, the poorest Walloon province, still had a higher income per head than the 'richest' Flemish province, Antwerp.

The bad economic performance of much of northern Belgium was to a large extent due to the collapse of the Flemish rural linen industry in the mid-19 ${ }^{\text {th }}$ century. Blown away by competition from British mechanized production the Flemish countryside suffered from massive structural under- and unemployment for decades to come. To a certain degree the Flemish fate resembled that of the Irish: emigration to Wallonia, France and to a lesser extent overseas was often the only solution to escape poverty.

In the late $19^{\text {th }}$ century the countryside was struck by the agricultural invasion, massive exports of grain by the New World, which put severe downward 
pressure on the profitability of arable farming. The resulting shift to animal husbandry again affected rural employment negatively so that the Flemish countryside continued to suffer from an excess labour supply (Verhaegen, 1961; Blomme, 1993). An element of hope however was the port of Antwerp. It benefitted from good rail- and waterway connections with the rapidly growing industrial areas in Wallonia, western Germany and northern France. The sharply rising volume of transhipments stimulated employment, not only of dock-workers, but also in port-related industries - food processing and ship-repair - and services such as logistics, wholesale and finance (Loyen, Buyst and Devos, 2003).

Map 1: Relative regional GDP per capita in 1896 (current prices, Belgium = 100) 




Source: see text.

In 1896 Belgium's economic power house was undoubted the Walloon manufacturing belt, stretching from the Borinage close to the French border until Verviers located near Germany. Based on rich coal deposits and nearby iron ore mines the area participated vigorously in the so-called first industrial revolution of the early and mid- $19^{\text {th }}$ century. It rapidly became one of the most important manufacturing centres in Europe and kept that role until the beginning of the $20^{\text {th }}$ century (Pollard, 1982; Broadberry, Federico and Klein, 2009). Backbone of this success story was the thriving steel, glass and machine-building industries. Walloon entrepreneurs also participated enthusiastically in the so-called first global economy of the late $19^{\text {th }}$ and early 
$20^{\text {th }}$ centuries. They exported for instance locomotives and other transport equipment, high valued added products in those days, to all corners of the world (Wautelet, 1995).

Brabant, symbolically located in the middle of the country and counting both Dutch- and French-speakers, took an intermediary position between Flanders and Wallonia. It benefitted from the expanding luxury industries - paper and printing, specialized food processing - and tertiary activities in and around Brussels.

In 1937 the geographical distribution of relative GDP per capita had changed considerably compared to 1896. Map 2 indicates that Brabant became Belgium's richest province and that the divide between Flanders and Wallonia had lost some of its intensity. The two most populated French-speaking provinces - Hainaut and Liège - still boasted an above average per capita GDP but less pronounced so than forty years earlier. A newcomer in this league was the most populated Dutch-speaking province, Antwerp. The other Flemish provinces had also improved their relative position, while Luxemburg and Namur fell back. How can we explain these shifts? 
Map 2: Relative regional GDP per capita in 1937 (current prices, Belgium = 100)



Source: see text.

Already in the late $19^{\text {th }}$ and early $20^{\text {th }}$ centuries the catching-up of northern Belgium had gained momentum. Based on low wages, the mechanized textile industry showed continuous growth in East and West Flanders. Moreover, Wallonia's coal mines were confronted with the first signs of exhaustion. This necessitated increasing imports of coal from overseas which encouraged the construction of new coke smelting plants in the neighbourhood of the ports of Antwerp, Ghent and Zeebrugge. The by-products of these facilities - gas, tar, 
ammonia, etc. - often attracted in their turn chemical and other industries. Linguistically mixed Brabant benefitted strongly from the same mechanism. Especially the canal linking the river Scheldt with Brussels and Charleroi became in the first decades of the $20^{\text {th }}$ century a major and diversified manufacturing axis (Olyslager, 1947; Buyst and Lefebvre, 2007).

The flourishing port of Antwerp managed to attract important new industries, such as the production of telephone equipment (Bell Telephone), photographic paper and cars (Minerva, Ford, General Motors). The discovery of rich copper and cobalt deposits in Congo gave rise to a rapidly expanding non ferrous metals industry (Union Minière). Limburg became a coal mining area in the 1920s and 1930s, but the hope that this would generate a modern steel industry in the area never materialized. Limburg remained a supplier of energy to Wallonia (Pinxten, 1937).

During World War I the Walloon manufacturing belt was badly hit by German dismantlement and plunder. After the Armistice the reconstruction effort proceeded swiftly, but it produced more often than not a copy of the prewar setting. In the steel industry, for instance, an opportunity was missed to set up large-scale specialized plants that could adopt American mass production techniques (Geerkens, 2004). On the demand side, the important export of locomotives and rolling stock was undermined by the nationalization of railway networks in many countries, the emergence of import-substitution policies, and the breakthrough of cars and lorries. Consequently the metallurgical sector focused more and more on the export of semi-finished products (Maizels, 1963).

The fast relative decline of Luxemburg and Namur probably has to be nuanced. Table 1 already indicated that the Geary and Stark method produces less accurate results for these provinces. Nevertheless it is clear that their relative specialization in agriculture, clothing and wood industries did not favour their growth performance. Conversely, the absence of big or even medium-sized cities deprived them from the stimulus given by the thriving tertiary sector in the interwar period (De Brabander, 1981). 
Map 3: Relative regional GDP per capita in 1947 (current prices, Belgium = 100)

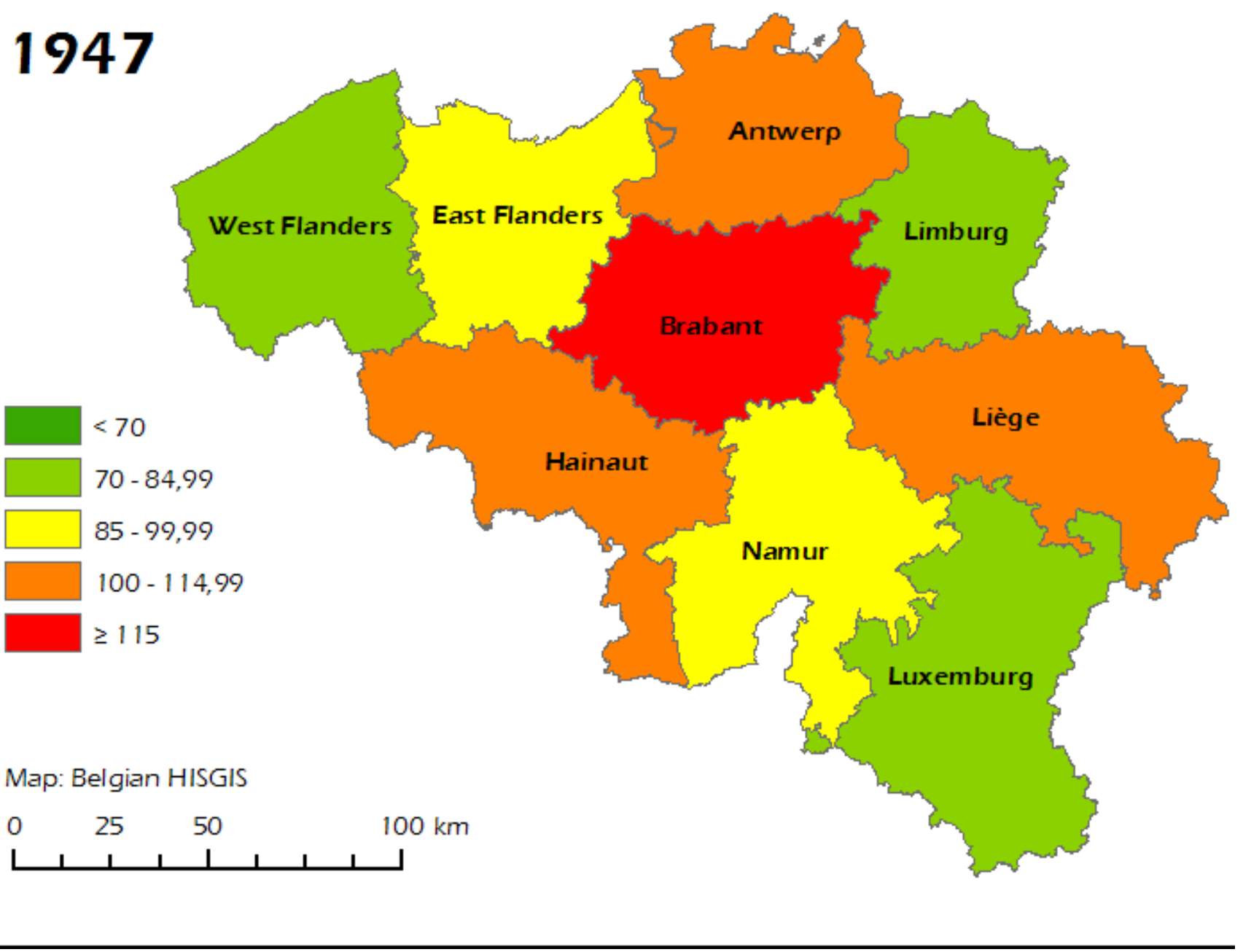

Source: see text.

The 1947 geographical distribution of relative GDP per capita (map 3) resembles very much that of 1937 . The short time span between the two observations is an obvious explanation, but there is more at hand. Belgian industry survived World War II without much damage. The Walloon manufacturing belt benefitted enormously from this situation as it was 
specialized in products that were very much in demand during the reconstruction of Europe, such as steel, metal products, glass and cement (Baudhuin, 1958). As a result, the catching-up process of the northern provinces stalled.

Map 4: Relative regional GDP per capita in 1970 (current prices, Belgium = 100)

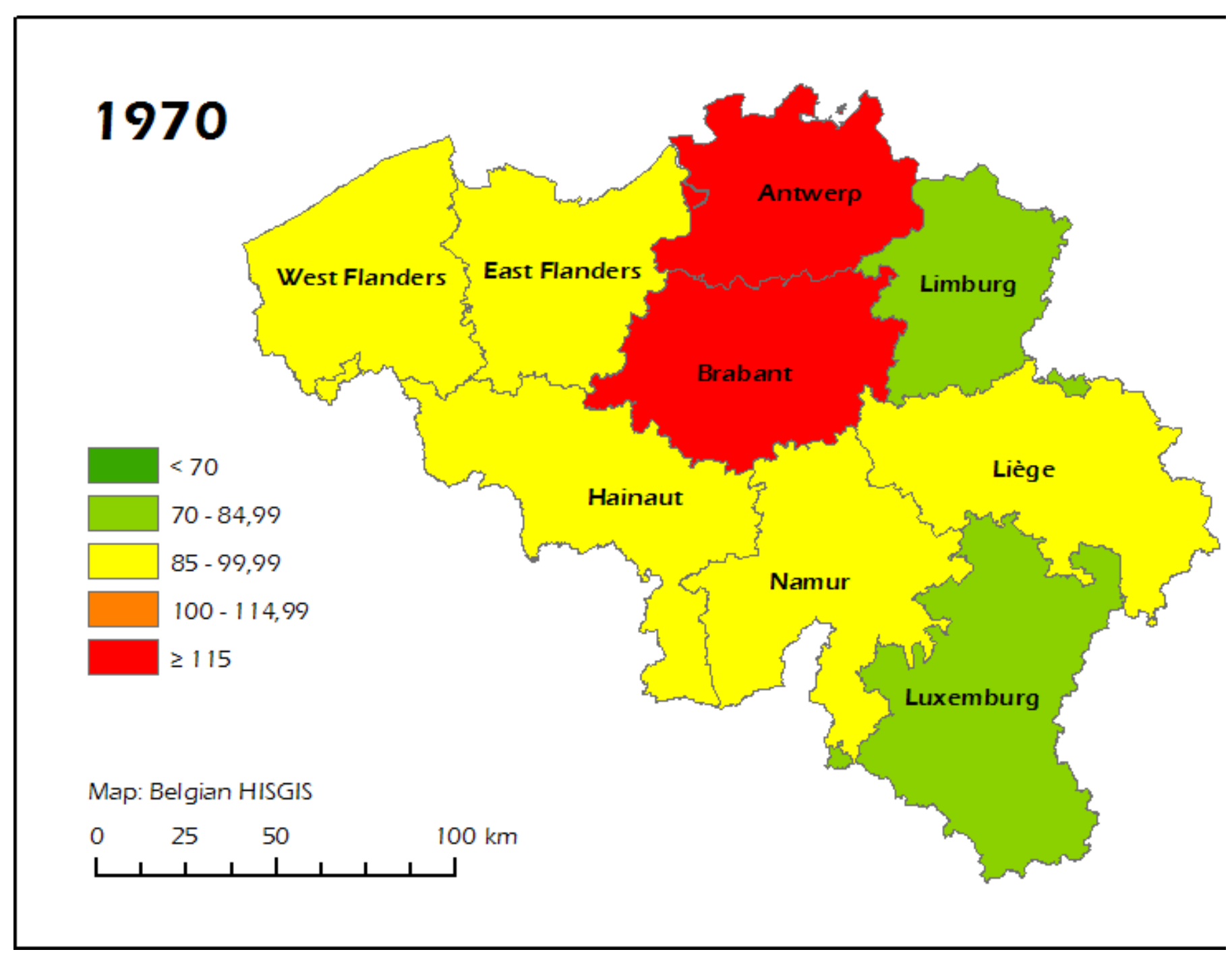

Source: NIS (1976). 
In 1970 the geographical distribution of relative GDP per capita looked considerably different compared to the 1947 situation. The provinces Hainaut and Liège fell below the Belgian average, while the province of Antwerp managed to strengthen its position. What had happened to the former power house of the Belgian economy?

The breakthrough of oil as a major source of energy in the mid-1950s brought the latent profitability problems in the coal mining sector brutally to the surface. Dozens of mines had to be closed down, causing the loss of a key industry in Wallonia. The government responded in 1959 to these and other problems by launching the so-called expansion laws, the Belgian variant of regional policy. A whole range of tax incentives and the development of wellequipped industrial sites should lure (foreign) investments to areas facing structural difficulties. But too little avail for Hainaut and Liège: the historically high wages prevailing in the coal mining industry had pushed up wage costs in other sectors too. Due to labour market rigidities it proved very difficult to bring these wages down again even after the collapse of coal mining. Competitiveness problems and adverse labour relations often deterred potential investors (Baudhuin, 1970; De Grauwe, 1980; Brion and Moreau, 1998).

Conversely the ports in the northern provinces benefitted strongly from the breakthrough of oil. Massive transhipments of the 'new black gold' attracted oil refineries and petrochemical plants. The area also took advantage of the process of European economic integration. After the Treaty of Rome (1957) many multinational companies were seeking locations for new production facilities in the EEC. The northern provinces with their relatively low wages, easy access to the sea and to a densely populated hinterland received a large inflow of foreign direct investment. As a result, metal processing and the production of consumer durables expanded rapidly. It more than compensated for the decline in textiles, clothing and - in Limburg - coal mining (Van der Wee, 1997). 
Brabant was, as always, very dependent on the developments in Brussels. In a highly centralized country the expansion of the welfare state led to a rapidly growing public sector in the capital city. Trade and finance also went up and compensated for the relative deindustrialization of the capital city. Commuting to Brussels became a way of life for many workers living in Flanders and increasingly so in Wallonia.

Finally we look at the geographical distribution of relative GDP per capita in the year 2000 (map 5 and annex 2). It shows that the oil shocks of the 1970s and their aftermath hit southern Belgium particularly hard. Because of growing international competition Wallonia's important steel industry had to go through a phase of substantial downsizing. Several old industrial areas in western Europe faced a similar process of structural adjustment, but in contrast with e.g. Glasgow or Bilbao a successful reconversion to tertiary activities never materialized. To the contrary, in the 1980s and 1990s high unemployment rates pushed the provinces of Hainaut and Liège still deeper into the economic mire. Massive subsidies, since the 1980s also from EU-funds, could not prevent that Hainaut became Belgium's poorest province. One reason is that the Belgian system of national wage bargaining became more and more rigid in the 1970 s and ultimately left almost no room for regional wage rate divergence. So it proved very difficult to bring wages in line with a declining relative labour productivity performance, which continued to undermine the region's competitive position (Estevao, 2003).

Northern Belgium also experienced hard times in the late 1970s and early 1980s. The textile and clothing industries received another battering and shipbuilding literally disappeared from the economic scene. But afterwards the region managed to take part in a general European recovery. Antwerp became one of the continent's major chemical clusters; the textile and nonferrous metals industry found new niche markets, such as carpets and composite materials (Loyen, Buyst and Devos, 2003). 
Map 5: Relative regional GDP per capita in 2000 (current prices, Belgium = 100)

\section{0}


$70-84,99$

$\square 85-99,99$

$100-114,99$

$\geq 115$

Map: Belgian HISGIS


Source: www.belgostat.be domein 799, table 10.

Another crucial development was the revival of European integration from the mid-1980s onwards. Brussels, the seat of the Commission and the Council, became more and more recognized as 'the capital of Europe'. As a result Brussels became a magnet for European headquarters of many multinational firms. This stimulated other high value added services such as financial intermediation and business-to-business activities (legal advice, consultancy, real estate, etc.). In this context it comes as no surprise that per capita GDP in 
Brussels and its surroundings - Brabant - soared. Northern Belgium participated in the bonanza by attracting several distribution centres of multinational firms (Buyst, 1997).

Did the reversal of fortune in Belgium lead to convergence? The standard deviations presented in Annex 2 provide an answer to this question. It shows strong convergence between 1896 and 1947. Thereafter the process slowed down despite the launching of regional policies in 1959. Between 1970 and 2000 we notice a rapidly rising regional inequality, so that in 2000 the standard deviation again reached the level of 1896.

These results are very much in line with those of Crafts (2005) for Britain. As the economic structure of Britain and Belgium shared many similarities - e.g. two early industrializers - this is not too surprising. Nevertheless, there are also marked differences between the two countries. In contrast to Belgium, Britain was a fairly protectionist country between the early 1930 s and the 1970s (Broadberry and Crafts, 2003). It suggests that international mechanisms dictate more the economic convergence and divergence of regions than regional policies.

\section{Conclusion}

In the literature it is widely accepted that Flanders and Wallonia followed very distinct growth paths in the course of the $20^{\text {th }}$ century. This can be assessed quantitatively from 1955 on when the official regional accounts become available. In this paper we estimate regional GDP figures per capita for certain benchmark years in the first half of the $20^{\text {th }}$ century using the method proposed by Geary and Stark (2002).

In this paper we argue that the reversal of fortune between Wallonia and Flanders over the last century was largely due to the interplay of energy sources, international economic developments and policy mistakes. 
Our estimates confirm for 1896 the clear divide between a 'poor Flanders' and a 'prosperous Wallonia'. Southern Belgium was a typical child of the first industrial revolution and its resource-based economy. Rich coal deposits fired the thriving steel, glass and machine-building industries. But in a small economy possessing the right resources is certainly not a sufficient condition for growth. It has to be complemented with a successful penetration in foreign markets. Entrepreneurship opened up the opportunities provided by the first global economy. Conversely, most of northern Belgium suffered from the chill winds of international competition because of inefficient production methods. The rural linen industry was blown away by British mechanized production and later on arable farming received a battering from the agricultural invasion.

In the first half of the $20^{\text {th }}$ century structural changes affected Wallonia and Flanders in a different way. The Walloon coal mines suffered from exhaustion and the exports of rolling stock proved vulnerable to protectionism. Flanders, on the other hand, started capitalizing on its easy access to the sea. Growing imports of coal and of copper from the Belgian Congo gave rise to new manufacturing plants in port areas.

The breakthrough of oil in the 1950s broke the backbone of Wallonia's resource-based economy. A decade later most coal mines were closed down. Increased international competition led to a substantial downsizing of the steel industry in the 1980s. Other old industrial areas in Europe shared the same fate, but government induced labour market rigidities prevented in the Walloon case a successful economic reconversion. Flanders on the other side benefitted fully from the maritimization of key industrial sectors such as oil refining and chemicals. It also attracted large inflows of foreign direct investment, which modernized further its industrial structure. More recently the setting-up of several distribution centres of multinational firms gave its transit function another boost.

Brabant, symbolically located in the middle of the country and counting both Dutch- and French-speakers, took advantage of the expansion of Brussels and its surroundings. In the decades following World War II the city benefitted 
from the rapidly growing Belgian state bureaucracy. From the mid-1980 Brussels managed to profile itself as 'the capital of Europe'. In that role it attracted high value added services. 


\section{References}

Annuaire statistique de la Belgique (et du Congo belge) (1923-1924; 1962 ; 1963). Brussels: Ministère de l'Intérieur.

BAUDHUIN, F. (1958), Histoire économique de la Belgique 1945-1956. Brussels: Bruylant.

BAUDHUIN, F. (1970), Histoire économique de la Belgique 1957-1958. Brussels: Bruylant.

BLOMME, J. (1993), The Economic Development of Belgian Agriculture: 1880-1980. A Quantitative and Qualitative Analysis. Leuven: University Press.

BRION, R. and MOREAU J.-L., La Société Générale de Belgique 1822-1997. Antwerp: Fonds Mercator.

BROADBERRY, S. and CRAFTS, N. (2003), UK Productivity Performance from 1950 to 1979: A Restatement of the Broadberry-Crafts View. Economic History Review, 56, pp. 718-735.

BROADBERRY, S., FEDERICO, G. and KLEIN, A. (2009), Sectoral Developments, 1870-1914. In S. Broadberry and K. O'Rourke (eds.), Cambridge Economic History of Modern Europe. Cambridge: University Press, forthcoming.

BUYST, E. (1997), The Decline an Rise of a Small Open Economy: The Case of Belgium (1974-1990). In H. Van der Wee en J. Blomme (eds.), The Economic Development of Belgium Since 1870. Cheltenham-Lyme: Elgar, pp. 67-76.

BUYST, E. and LEFEBVRE, W. (2007), Enkele verklaringsfactoren voor de regional gedifferentieerde industriële ontwikkeling van Vlaams-Brabant tussen 
1896 en 1961. Belgisch Tijdschrift voor Nieuwste Geschiedenis, 37, pp. 4177.

CDS (1939), Economische en sociale telling van 27 februari 1937. Enquête nopens het arbeidstelsel en de loonen in den landbouw, Brussels: Centrale Dienst voor de Statistiek.

CDS (1940), Economische en sociale telling van 27 februari 1937, vols IV-V. Brussels: Centrale Dienst voor de Statistiek.

CONWAY, M. (2005), Belgium's Mid-Twentieth Century Crisis: Crisis of a Nation State? Belgisch Tijdschrift voor Nieuwste Geschiedenis, 35, pp. 573596.

CRAFTS, N. (2005), Regional GDP in Britain, 1871-1911: Some Estimates. Scottish Journal of Political Economy, 52, pp. 54-64.

DE BRABANDER, G.L. (1981). Regional Specialization, Employment and Economic Growth in Belgium between 1846 and 1970. New York: Arno Press.

DE GRAUWE, P. (1980), Aspecten van de economische achteruitgang van Wallonië, Tijdschrift voor Economie en Management, 25, pp. 225-243.

DEPREZ, K. and VOS, L. eds. (1998), Nationalism in Belgium: Shifting Identities. Basingstoke: Macmillan.

ESTEVAO, M. (2003), Regional labor market disparities in Belgium. Reflets et Perspectives, 42, pp. 95-114.

GEARY, F. and STARK, T. (2002), Examining Ireland's Post-Famine Economic Growth Performance. Economic Journal, 112, pp. 919-935.

GEERKENS, E. (2004), La rationalisation de l'industrie belge de l'Entre-deuxguerres. 2 Vols.,Brussels: Académie royale de Belgique. 
GoOSSENS, M. (2003). The Flemish Parliament. Tielt: Lannoo.

HANNES, J. (2007). De mythe van de omgekeerde transfers. Fiscale prestaties van Vlaanderen, Wallonië en Brabant 1832-1912. Roeselare: Roularta Books.

INR (1999), Regionale Rekeningen. Economische groei van de gewesten, provincies en arrondissementen - periode 1985-1997. Methodologische nota. Brussels: Instituut voor de Nationale Rekeningen.

LEI (1961), Verslag over de resultaten van 73 analytische landbouwboekhoudingen. Brussels: Landbouw-economisch Instituut.

LOYEN, R., BUYST, E. and DEVOS, G. eds. (2003), Struggling for Leadership: Antwerp-Rotterdam Port Competition between 1870-2000. Heidelberg: Physica-Verlag.

MAIZELS, A. (1963), Industrial Growth and World Trade. Cambridge: University Press.

MATP (1900), Agriculture. Recensement général de 1895. Partie analytique, Brussels: Ministère de l'Agriculture et des Travaux Publics.

Ministerie van Landbouw (1948), Lonen in de landbouw, Landbouwtijdschrift, 1, p. 54.

MIT (1901), Recensement général des industries et des métiers (31 octobre 1896), vols. IX-XIV. Brussels: Ministère de I'Industrie et du Travail.

NIS (1951-1952), Algemene Volks-, Nijverheids- en Handelstelling op 31 december 1947, vols. XI-XII, Brussels: Nationaal Instituut voor de Statistiek. 
NIS (1966), Economische groei van de provincies en taalstreken van 1955 tot 1963. (Statistische en econometrische studiën, nr. 12). Brussels: Nationaal Instituut voor de Statistiek.

NIS (1976), Economische groei van de provincies en de taalstreken van 1970 tot 1974. (Statistische en econometrische studiën, nr. 43). Brussels: Nationaal Instituut voor de Statistiek.

OLYSLAGER, P. (1947), De localiseering der Belgische nijverheid. Antwerp: Standaard.

PINXTEN, K. (1937), Het Kempisch steenkolenbekken: een economische studie. Brussels: Standaard.

POLLARD, S. (1982), Peaceful Conquest. The Industrialization of Europe 1760-1970. Oxford: University Press.

RMZ (1961), Jaarverslag. Brussels: Rijksdienst voor Maatschappelijke Zekerheid.

SCHOLLIERS, P. (1991), Industrial wage differentials in nineteenth-century Belgium. In Y.S. Brenner, H. Kaelble and M. Thomas (eds.), Income Distribution in Historical Perspective. Cambridge: University Press, pp. 96116.

SMITH, D.M. and WISTRICH, E. (2007), Regional Identity and Diversity in Europe: Experience in Wales, Silesia and Flanders. London: Federal Trust.

SOETE, A. (1999), Het Belgisch BBP 1910-1953. Unpublished paper: Centre for Economic Studies, University of Leuven.

VAN DER WEE (1997), The Economic Challenge Facing Belgium in the $19^{\text {th }}$ and $20^{\text {th }}$ Centuries. In H. Van der Wee en J. Blomme (eds.), The Economic Development of Belgium Since 1870. Cheltenham-Lyme: Elgar, pp. 52-66. 
VERHAEGEN, B. (1961), Contribution à l'histoire économique des Flandres, 2 vols. Leuven-Paris: Nauwelaerts.

WAUTELET, J.-M. (1995), Structures industrielles et reproduction élargie du capital en Belgique (1850-1914). Louvain-la-Neuve: Academia.

WITTE, E. (1983), Une Flandre appauvri. In E. Witte (ed.), Histoire de Flandre des origines à nos jours. Brussels: La Renaissance du Livre, pp. 181-245.

WitTE, E. and VAN VELTHOVEN, H. (1999), Language and Politics. The Belgian Case Study in a Historical Perspective. Brussels: VUBpress. 


\section{Annexes}

Annex 1: Sector employment in Belgium by province, 1896-1961

\begin{tabular}{|l|r|r|r|r|r|r|}
\hline & \multicolumn{4}{|c|}{1896} & \multicolumn{3}{c|}{1961} \\
\hline & Agricult. & Industry & Services & Agricult. & Industry & Services \\
\hline Antwerp & 76.669 & 82.928 & 98.800 & 27.330 & 243.376 & 250.979 \\
\hline Brabant & 127.396 & 159.354 & 168.400 & 37.788 & 347.752 & 475.391 \\
\hline West Flan. & 119.244 & 62.806 & 87.300 & 40.917 & 172.611 & 143.006 \\
\hline East Flan. & 148.115 & 126.587 & 106.500 & 44.694 & 214.424 & 159.065 \\
\hline Hainaut & 89.735 & 253.837 & 116.800 & 26.719 & 215.179 & 155.311 \\
\hline Liège & 54.465 & 166.916 & 88.700 & 25.835 & 203.889 & 151.610 \\
\hline Limburg & 52.691 & 15.958 & 24.800 & 17.918 & 78.025 & 62.276 \\
\hline Luxemburg & 53.938 & 17.506 & 22.600 & 16.734 & 16.684 & 27.769 \\
\hline Namur & 50.697 & 51.373 & 40.700 & 14.592 & 42.565 & 53.987 \\
\hline Total & 772.950 & 937.265 & 754.600 & 252.527 & 1.534 .505 & 1.479 .394 \\
\hline
\end{tabular}

Source: De Brabander (1981). 
Annex 2: Relative regional GDP, 1896-2000 (current prices, Belgium = 100)

\begin{tabular}{|l|r|r|r|r|r|}
\hline & \multicolumn{1}{|c|}{1896} & \multicolumn{1}{|c|}{1937} & \multicolumn{1}{c|}{1947} & \multicolumn{1}{c|}{1970} & \multicolumn{1}{c|}{2000} \\
\hline Antwerp & 91,1 & 107,3 & 106,9 & 115,1 & 117,3 \\
\hline Brabant & 104,0 & 119,6 & 120,6 & 118,6 & 142,2 \\
\hline West Flan. & 64,2 & 77,7 & 76,3 & 97,3 & 93,3 \\
\hline East Flan. & 80,5 & 85,9 & 85,1 & 87,9 & 86,8 \\
\hline Hainaut & 136,0 & 105,1 & 103,3 & 86,5 & 66,3 \\
\hline Liège & 119,9 & 111,5 & 110,5 & 98,9 & 75,5 \\
\hline Limburg & 63,7 & 75,4 & 80,1 & 77,8 & 84,0 \\
\hline Luxemburg & 94,4 & 66,4 & 77,3 & 73,2 & 70,3 \\
\hline Namur & 109,9 & 84,5 & 87,8 & 85,2 & 69,1 \\
\hline $\begin{array}{l}\text { Standard } \\
\text { deviation }\end{array}$ & 24,4 & 18,6 & 16,4 & 15,6 & 25,3 \\
\hline
\end{tabular}

Source: 1896-1947: see text.

1970: NIS (1976)

2000: www.belgostat.be, domein 799, table 10. 